\section{A BIRD TRIANGLE}

\section{MARGARET J. COPE, Calgary}

This spring three Tree Swallows, two males and a female, arrived in a friend's garden and began at once to investigate the possibilities of a bird house there. They liked what they found and proceeded to build and set up housekeeping-all three of them. True, there were days when there seemed to be much bickering and scolding, but on the whole things. went smoothly, with one bird on the nest and two outside on the clothesline.

In due course the eggs hatched and all three birds worked ceaselessly carrying food. In and out they flitied, barely pausing long enough to drop the morsel before they were away again.

Finally the head of a baby swallow appeared in the doorway of the kox. There followed several days of indecision - junior just wouldn't emerge fully. All three "parents" took to coaxing, scolding, pleadinghe wouldn't budge, other than to disappear inside. At last the trio wearied of it all; they fed the youngsters a final breakfast and flew away. All day long the little birds waited quietly (usually they maintained an incessant clamour); nothing happened. Finally hunger compelled them to come out. They launched forth into the air with surprisingly strong flight, and soon disappeared. Neither they, nor the threesome who reared them, have returned.

NOTE: It is just this past spring that I have joined the ranks of those who delight in watching and becoming acquainted with birds. I bought binoculars, and was loaned waders; the watching of shore birds has opened up a whole new world of pleasure. It has been my good fortune to go out with two excellent birdmen, both of whom have in abundance one of life's greatest gifts -enthusiasm. I never dreamed that an afternoon spent stalking and squooshing around in the rank grasses of a slough could afford such satisfaction, that there were so many ducks with such beautiful plumage in spring, or so many graceful dainty little birds along the margins of even the smallest pond.

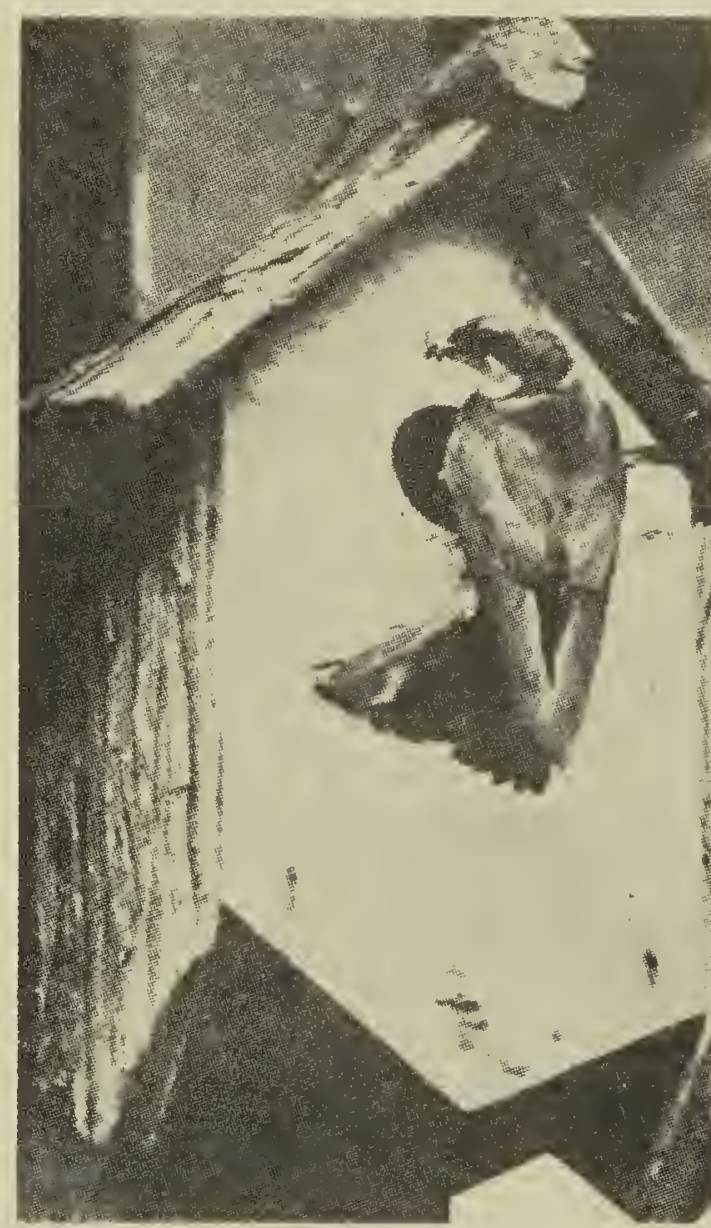

With the habits of perching birds I am less acquainted. Perhaps one of your members would tell me if young swallows are always so difficult to get out of the nest, or if these particular ones, being the offspring of rather unusual parents, were unique. Other observers might be able to tell of their experiences with tree swallows.

Editor's Note: In the summer of 1951, a similar incident happened in my own back yard in Regina. The two male birds took their turn at feeding the young. As they were catching insects they would seem to chase one another in a great circle, always going and returning in the same direction and always pausing to rest about eight feet apart on the clothesline. There they would gaze, first at the grass and garden below as if in deep meditation and then at the nesting box where their mutual mate was attending to her maternal duties. Unfortunately we left home for a few days and have no knowledge about the departure of the young.

\section{ADDITIONAL PATRONS FOR 1953}

Kenneth Knox ... ... Clair, Sask. Lad. Martinovsky, Gerald, Sask. 